\title{
Psikologi Humanistik dan Aplikasinya dalam Pendidikan
}

\author{
Ratna Syifa'a Rachmahana ${ }^{1}$
}

\begin{abstract}
Abstrak
Psikologi humanistik atau disebut juga dengan nama psikologi kemanusiaan adalah suatu pendekatan yang multifaset terhadap pengalaman dan tingkah laku manusia, yang memusatkan perhatian pada keunikan dan aktualisasi diri manusia. Bagi sejumlah ahli psikologi humanistik ia adalah alternatif, sedangkan bagi sejumlah ahli psikologi humanistik yang lainnya merupakan pelengkap bagi penekanan tradisional behaviorisme dan psikoanalis.

Psikologi humanistik juga memberikan sumbangannya bagi pendidikan alternatif yang dikenal dengan sebutan pendidikan humanistik (humanistic education). Pendidikan humanistik berusaha mengembangkan individu secara keseluruhan melalui pembelajaran nyata. Pengembangan aspek emosional, sosial, mental, dan keterampilan dalam berkarier menjadi fokus dalam model pendidikan humanistic.

Aliran Psikologi Humanistik selalu mendorong peningkatan kualitas diri manusia melalui penghargaannya terhadap potensi-potensi positif yang ada pada setiap insan. Seiring dengan perubahan dan tuntutan zaman, proses pendidikan pun senantiasa berubah.
\end{abstract}

Kata kunci: psikologi, humanistik, pendidikan

\section{A. Pendahuluan}

Aliran humanistik muncul pada tahun 1940-an sebagai reaksi ketidakpuasan terhadap pendekatan psikoanalisa dan behavioristik. Sebagai sebuah aliran dalam psikologi, aliran ini boleh dikatakan relatif masih muda, bahkan beberapa ahlinya masih hidup dan

${ }^{1}$ Dosen Fakultas Psikologi dan Ilmu Sosial Budaya UII Yogyakarta. 
terus-menerus mengeluarkan konsep yang relevan dengan bidang pengkajian psikologi, yang sangat menekankan pentingnya kesadaran, aktualisasi diri, dan hal-hal yang bersifat positif tentang manusia.

Dalam tulisan singkat ini akan dijelaskan mulai dari tokohtokoh penting dalam aliran humanistik dan teorinya yang relevan dengan psikologi pendidikan, dan diakhiri dengan aplikasi psikologi humanistik dalam dunia pendidikan, khususnya dalam proses pembelajaran.

\section{B. Tokoh-tokoh Penting dalam Aliran Humanistik dan Teorinya}

\section{Abraham Maslow}

Abraham H. Maslow (selanjutnya ditulis Maslow) adalah tokoh yang menonjol dalam psikologi humanistik. Karyanya di bidang pemenuhan kebutuhan berpengaruh sekali terhadap upaya memahami motivasi manusia. Sebagian dari teorinya yang penting didasarkan atas asumsi bahwa dalam diri manusia terdapat dorongan positif untuk tumbuh dan kekuatan-kekuatan yang melawan atau menghalangi pertumbuhan (Rumini, dkk. 1993).

Maslow berpendapat, bahwa manusia memiliki hierarki kebutuhan yang dimulai dari kebutuhan jasmaniah-yang paling asasi- sampai dengan kebutuhan tertinggi yakni kebutuhan estetis. Kebutuhan jasmaniah seperti makan, minum, tidur dan sex menuntut sekali untuk dipuaskan. Apabila kebutuhan ini terpuaskan, maka muncullah kebutuhan keamanan seperti kebutuhan kesehatan dan kebutuhan terhindar dari bahaya dan bencana. Berikutnya adalah kebutuhan untuk memiliki dan cinta kasih, seperti dorongan untuk memiliki kawan dan berkeluarga, kebutuhan untuk menjadi anggota kelompok, dan sebagainya. Ketidakmampuan memenuhi kebutuhan ini dapat mendorong seseorang berbuat lain untuk memperoleh pengakuan dan perhatian, misalnya dia menggunakan prestasi sebagai pengganti cinta kasih. Berikutnya adalah kebutuhan harga diri, yaitu kebutuhan untuk dihargai, dihormati, dan dipercaya oleh orang lain.

Apabila seseorang telah dapat memenuhi semua kebutuhan yang tingkatannya lebih rendah tadi, maka motivasi lalu diarahkan kepada terpenuhinya kebutuhan aktualisasi diri, yaitu kebutuhan 
untuk mengembangkan potensi atau bakat dan kecenderungan tertentu. Bagaimana cara aktualisasi diri ini tampil, tidaklah sama pada setiap orang. Sesudah kebutuhan ini, muncul kebutuhan untuk tahu dan mengerti, yakni dorongan untuk mencari tahu, memperoleh ilmu dan pemahaman. Sesudahnya, Maslow berpendapat adanya kebutuhan estetis, yakni dorongan keindahan, dalam arti kebutuhan akan keteraturan, kesimetrisan dan kelengkapan.

Maslow membedakan antara empat kebutuhan yang pertama dengan tiga kebutuhan yang kemudian. Keempat kebutuhan yang pertama disebutnya deficiency need (kebutuhan yang timbul karena kekurangan), dan pemenuhan kebutuhan ini pada umumnya bergantung pada orang lain. Sedangkan ketiga kebutuhan yang lain dinamakan growth need (kebutuhan untuk tumbuh) dan pemenuhannya lebih bergantung pada manusia itu sendiri.

Implikasi dari teori Maslow dalam dunia pendidikan sangat penting. Dalam proses belajar-mengajar misalnya, guru mestinya memperhatikan teori ini. Apabila guru menemukan kesulitan untuk memahami mengapa anak-anak tertentu tidak mengerjakan pekerjaan rumah, mengapa anak tidak dapat tenang di dalam kelas, atau bahkan mengapa anak-anak tidak memiliki motivasi untuk belajar. Menurut Maslow, guru tidak bisa menyalahkan anak atas kejadian ini secara langsung, sebelum memahami barangkali ada proses tidak terpenuhinya kebutuhan anak yang berada di bawah kebutuhan untuk tahu dan mengerti. Bisa jadi anak-anak tersebut belum atau tidak melakukan makan pagi yang cukup, semalam tidak tidur dengan nyenyak, atau ada masalah pribadi / keluarga yang membuatnya cemas dan takut, dan lain-lain.

\section{Carl R. Rogers}

Carl R. Rogers adalah seorang ahli psikologi humanistik yang gagasan-gagasannya berpengaruh terhadap pikiran dan praktek psikologi di semua bidang, baik klinis, pendidikan, dan lain-lain. Lebih khusus dalam bidang pendidikan, Rogers mengutarakan pendapat tentang prinsip-prinsip belajar yang humanistik, yang meliputi hasrat untuk belajar, belajar yang berarti, belajar tanpa ancaman, belajar atas inisiatif sendiri, dan belajar untuk perubahan (Rumini,dkk. 1993).

Adapun penjelasan konsep masing-masing prinsip tersebut adalah sebagai berikut :

a. Hasrat untuk Belajar 
Menurut Rogers, manusia mempunyai hasrat alami untuk belajar. Hal ini terbukti dengan tingginya rasa ingin tahu anak apabila diberi kesempatan untuk mengeksplorasi lingkungan. Dorongan ingin tahu untuk belajar ini merupakan asumsi dasar pendidikan humanistik. Di dalam kelas yang humanistik anak-anak diberi kesempatan dan kebebasan untuk memuaskan dorongan ingin tahunya, untuk memenuhi minatnya dan untuk menemukan apa yang penting dan berarti tentang dunia di sekitarnya.

b. Belajar yang Berarti

Belajar akan mempunyai arti atau makna apabila apa yang dipelajari relevan dengan kebutuhan dan maksud anak. Artinya, anak akan belajar dengan cepat apabila yang dipelajari mempunyai arti baginya.

c. Belajar Tanpa Ancaman

Belajar mudah dilakukan dan hasilnya dapat disimpan dengan baik apabila berlangsung dalam lingkungan yang bebas ancaman. Proses belajar akan berjalan lancer manakala murid dapat menguji kemampuannya, dapat mencoba pengalaman-pengalaman baru atau membuat kesalahan-kesalahan tanpa mendapat kecaman yang bisaanya menyinggung perasaan.

d. Belajar atas Inisiatif Sendiri

Belajar akan paling bermakna apabila hal itu dilakukan atas inisiatif sendiri dan melibatkan perasaan dan pikiran si pelajar. Mampu memilih arah belajarnya sendiri sangatlah memberikan motivasi dan mengulurkan kesempatan kepada murid untuk "belajar bagaimana caranya belajar" (to learn how to learn ). Tidaklah perlu diragukan bahwa menguasai bahan pelajaran itu penting, akan tetapi tidak lebih penting daripada memperoleh kecakapan untuk mencari sumber, merumuskan masalah, menguji hipotesis atau asumsi, dan menilai hasil. Belajar atas inisiatif sendiri memusatkan perhatian murid baik pada proses maupun hasil belajar.

Belajar atas inisiatif sendiri juga mengajar murid menjadi bebas, tidak bergantung, dan percaya pada diri sendiri. Apabila murid belajar atas inisiatif sendiri, ia memiliki kesempatan untuk menimbang-nimbang dan membuat keputusan, menentukan pilihan dan melakukan penilaian. Dia menjadi lebih bergantung pada dirinya sendiri dan kurang bersandar pada penilaian pihak lain.

Di samping atas inisiatif sendiri, belajar juga harus melibatkan 
semua aspek pribadi, kognitif maupun afektif. Rogers dan para ahli humanistik yang lain menamakan jenis belajar ini sebagai whole-person learning, belajar dengan seluruh pribadi, belajar dengan pribadi yang utuh. Para ahli humanistik percaya, bahwa belajar dengan tipe ini akan menghasilkan perasaan memiliki (feeling of belonging ) pada diri murid. Dengan demikian, murid akan merasa terlibat dalam belajar, lebih bersemangat menangani tugas-tugas dan yang terpenting adalah senantiasa bergairah untuk terus belajar.

e. Belajar dan Perubahan

Prinsip terakhir yang dikemukakan oleh Rogers ialah bahwa belajar yang paling bermanfaat ialah bejar tentang proses belajar. Menurut Rogers, di waktu-waktu yang lampau murid belajar mengenai fakta-fakta dan gagasan-gagasan yang statis. Waktu itu dunia lambat brerubah, dan apa yang diperoleh di sekolah sudah dipandang cukup untuk memenuhi tuntutan zaman. Saat ini perubahan merupakan fakta hidup yang sentral. Ilmu Pengetahuan dan Teknologi selalu maju dan melaju. Apa yang dipelajari di masa lalu tidak dapat membekali orang untuk hidup dan berfungsi baik di masa kini dan masa yang akan dating. Dengan demikian, yang dibutuhkan saat ini adalah orang yang mampu belajar di lingkungan yang sedang berubah dan akan terus berubah.

\section{Arthur Combs}

Perasaan, persepsi, keyakinan dan maksud merupakan perilaku-perilaku batiniah yang menyebabkan seseorang berbeda dengan yang lain. Agar dapat memahami orang lain, seseorang harus melihat dunia orang lain tersebut, bagaimana ia berpikir dan merasa tentang dirinya. Itulah sebabnya, untuk mengubah perilaku orang lain, seseorang harus mengubah persepsinya.

Menurut Combs, perilaku yang keliru atau tidak baik terjadi karena tidak adanya kesediaan seseorang melakukan apa yang seharusnya dilakukan sebagai akibat dari adanya sesuatu yang lain, yang lebih menarik atau memuaskan. Misalkan guru mengeluh murid-muridnya tidak berminat belajar, sebenarnya hal itu karena murid-murid itu tidak berminat melakukan apa yang dikehendaki oleh guru. Kalau saja guru tersebut lalu mengadakan aktivitasaktivitas yang lain, barangkali murid-murid akan berubah sikap dan reaksinya (Rumini, dkk. 1993). 
Sesungguhnya para ahli psikologi humanistik melihat dua bagian belajar, yaitu diperolehnya informasi baru dan personalisasi informasi baru tersebut. Adalah keliru jika guru berpendapat bahwa murid akan mudah belajar kalau bahan pelajaran disusun dengan rapi dan disampaikan dengan baik, sebab arti dan maknanya tidak melekat pada bahan pelajaran itu; murid sendirilah yang mencerna dan menyerap arti dan makna bahan pelajaran tersebut ke dalam dirinya. Yang menjadi masalah dalam mengajar bukanlah bagaimana bahan pelajaran itu disampaikan, tetapi bagaimana membantu murid memetik arti dan makna yang terkandung di dalam bahan pelajaran tersebut, yakni apabila murid dapat mengaitkan bahan pelajaran tersebut dengan hidup dan kehidupan mereka, guru boleh bersenang hati bahwa missinya telah berhasil.

Semakin jauh hal-hal yang terjadi di luar diri seseorang (dunia) dari pusat lingkaran lingkaran (persepsi diri), semakin kurang pengaruhnya terhadap seseorang. Sebaliknya, semakin dekat hal-hal tersebut dengan pusat lingkaran, maka semakin besar pengaruhnya terhadap seseorang dalam berperilaku. Jadi jelaslah mengapa banyak hal yang dipelajari oleh murid segera dilupakan, karena sedikit sekali kaitannya dengan dirinya.

\section{Aldous Huxley}

Manusia memiliki banyak potensi yang selama ini banyak terpendam dan disia-siakan. Pendidikan diharapkan mampu membantu manusia dalam mengembangkan potensi-potensi tersebut, oleh karena itu kurikulum dalam proses pendidikan harus berorientasi pada pengembangan potensi, dan ini melibatkan semua pihak, seperti guru, murid maupun para pemerhati ataupun peneliti dan perencana pendidikan.

Huxley (Roberts, 1975) menekankan adanya pendidikan non-verbal yang juga harus diajarkan kepada siswa. Pendidikan non verbal bukan berwujud pelajaran senam, sepak bola, bernyanyi ataupun menari, melainkan hal-hal yang bersifat diluar materi pembelajaran, dengan tujuan menumbuhkan kesadaran seseorang. Proses pendidikan non verbal seyogyanya dimulai sejak usia dini sampai tingkat tinggi.

Betapapun, agar seseorang bisa mengetahui makna hidup dalam kehidupan yang nyata, mereka harus membekali dirinya dengan suatu kebijakan hidup, kreativitas dan mewujudkannya dengan langkah-langkah yang bijaksana. Dengan cara ini seseorang 
akan mendapatkan kehidupan yang nikmat dan penuh arti. Berbekal pendidikan non verbal, seseorang akan memiliki banyak strategi untuk lebih tenang dalam menapaki hidup karena memiliki kemampuan untuk menghargai setiap pengalaman hidupnya dengan lebih menarik. Akhirnya apabila setiap manusia memiliki kemampuan ini, akan menjadi sumbangan yang berarti bagi kebudayaan dan moral kemanusiaan.

\section{David Mills dan Stanley Scher}

Ilmu Pengetahuan Alam selama bertahun-tahun hanya dibahas dan dipelajari secara kognitif semata, yakni sebagai akumulasi dari fakta-fakta dan teori-teori. Padahal, bagaimanapun, praktek dari ilmu pengetahuan selalu melibatkan elemen-elemen afektif yang meliputi adanya kebutuhan akan pengetahuan, penggunaan intuisi dan imajinasi dalam usaha-usaha kreatif, pengalaman yang menantang, frustasi, dan lain-lain. Berdasarkan fenomena tersebut, David Mills dan Stanley Scher (Roberts, 1975) mengajukan konsep pendidikan terpadu, yakni proses pendidikan yang mengikutsertakan afeksi atau perasaan murid dalam belajar.

Metode afektif yang melibatkan perasaan telah bisaa diterapkan pada murid-murid untuk pelajaran IPS, Bahasa dan Seni. Sebetulnya ahli yang memulai merintis usaha ini adalah George Brown, namun kedua ahli ini kemudia mencoba melakukan riset yang bertujuan menemukan aplikasi yang lebih real dalam usaha tersebut. Penggunaan pendekatan terpadu ini dilakukan dalam pembelajaran IPA, pendidikan bisnis dan bahkan otomotif.

Pendekatan terpadu atau confluent approach merupakan sintesa dari Psikologi Humanistik -khususnya Terapi Gestalt- dan pendidikan, yang melibatkan integrasi elemen-elemen afektif dan kognitif dalam proses belajar. Elemen kognitif menunjuk pada berpikir, kemampuan verbal, logika, analisa, rasio dan cara-cara intelektual, sedangkan elemen afektif menunjuk pada perasaan, caracara memahami yang melibatkan gambaran visual-spasial, fantasi, persepsi keseluruhan, metaphor, intuisi, dan lain-lain.

Tujuan umum dari pendekatan ini adalah mengembangkan kesadaran murid-murid terhadap dirinya sendiri dan dunia sekitarnya, serta meningkatkan kemampuan untuk menggunakan kesadaran ini dalam menghadapi lingkungan dengan berbagai cara, menerima petunjuk-petunjuk internal dan menerima tanggung jawab bagi setiap pilihan mereka. Fungsi guru dalam pendekatan terpadu 
adalah untuk lebih membebaskan murid dari ketergantungan kepada guru, dengan tujuan akhir mengembangkan responsibilitas murid untuk belajar sendiri. Guru hanya membantu mereka dengan memberikan pilihan-pilihan yang masuk akal bagi pikiran mereka, dan jika perlu guru bisa menolak memberikan bantuan untuk halhal yang bisa ditangani oleh murid sendiri.

Lebih jauh, David Mills dan Stanley Scher memaparkan tujuan pendidikan terpadu ini secara detail sebagai berikut :

a. Membantu murid untuk mengalami proses ilmu pengetahuan, termasuk penemuan ide-ide baru, baik proses intelektual maupun afektif.

b. Membantu murid dalam mencapai kemampuan untuk menggali dan mengerti diri mereka sendiri dan lingkungan sekitarnya dengan cara yang ilmiah.

c. Meningkatkan pengertian dan ingatan terhadap konsep-konsep dan ide-ide dalam ilmu pengetahuan.

d. Menggali bersama-sama murid, implikasi-implikasi dari aplikasi yang mungkin dari ilmu pengetahuan.

e. Memungkinkan murid untuk menerapkan baik proses maupun pengetahuan ilmiah untuk diri mereka, serta meningkatkan kesadaran murid terhadap dunia mereka dan setiap pilihan yang mereka ambil.

Penerapan metode gabungan antara kognitif dan afektif ini menunjukkan hasil yang lebih efektif dibanding pengajaran yang hanya menekankan aspek kognitif. Para siswa merasa lebih cepat menangkap pelajaran dengan menggunakan fantasi, role playing dan game, misalnya mengajarkan teori Newton dengan murid berperan sebagai astronot.

\section{Aplikasi Aliran Humanistik Dalam Pendidikan}

Humanisme dalam Islam sebenarnya sudah terumuskan dalam konsep khalifatullah dalam Islam. Untuk mengerti konsep ini bisa dilacak pada sumber dasar Islam surat Al-Baqarah (2): 3032; yang substansinya ada tiga hal decara jelas diterangkan, yaitu: (1) manusia adalah pilihan Tuhan; (2) keberadaan manusia dengan segala kelebihannya dimaksudkan sebagai wakil Tuhan di atas bumu (khalifatullah fi al-ardl), dan (3) manusia adalah pribadi yang bebas yang menanggung segala risiko atas perbuatannya.

Terkait dengan konsep di atas, sistem pengajaran di lembaga 
pendidikan, termasuk lembaga pendidikan Islam yang bermasalah, paling tidak ditandai oleh beberapa hal berikut: (1) pengajaran materi secara umum termasuk pengajaran agama belum mampu melahirkan creativity. Akar masalah di sini terletak pada satu kenyataan bahwa bahan pengajaran di kurikulum kita terlalu overload; (2) morality atau akhlak di sekolah umum masih menjadi masalah utama, dan (3) punishment atau hukuman dalam berbagai bentuk lebih tampak dari reward atau penghargaan.

Berikut banyak sekali hal-hal yang merupakan aplikasi dari teori-teori humanistik, walaupun hanya akan ditampilkan sebagian aplikasi dalam proses pembelajaran, dikarenakan keterbatasan ruang dan waktu.

\section{Open Education atau Pendidikan Terbuka}

Pendidikan Terbuka adalah proses pendidikan yang memberikan kesempatan kepada murid untuk bergerak secara bebas di sekitar kelas dan memilih aktivitas belajar mereka sendiri. Guru hanya berperan sebagai pembimbing. Ciri utama dari proses ini adalah lingkungan fisik kelas yang berbeda dengan kelas tradisional, karena murid bekerja secara individual atau dalam kelompok-kelompok kecil. Dalam proses ini mensyaratkan adanya pusat-pusat belajar atau pusat-pusat kegiatan di dalam kelas yang memungkinkan murid mengeksplorasi bidang-bidang pelajaran, topik-topik, ketrampilanketrampilan atau minat-minat tertentu. Pusat ini dapat memberikan petunjuk untuk mempelajari suatu topik tanpa hadirnya guru dan dapat mencatat partisipasi dan kemajuan murid untuk nantinya dibicarakan dengan guru (Rumini, 1993).

Adapun kriteria yang disyaratkan dengan model ini adalah sebagai berikut :

a. Tersedia fasilitas yang memudahkan proses belajar, artinya berbagai macam bahan yang diperlukan untuk belajar harus ada. Murid tidak dilarang untuk bergerak secara bebas di ruang kelas, tidak dilarang bicara, tidak ada pengelompokan atas dasar tingkat kecerdasan.

b. Adanya suasana penuh kasih sayang, hangat, hormat dan terbuka. Guru menangani masalah-masalah perilaku dengan jalan berkomunikasi secara pribadi dengan murid yang bersangkutan, tanpa melibatkan kelompok.

c. Adanya kesempatan bagi guru dan murid untuk bersamasama mendiagnosis peristiwa-peristiwa belajar, artinya murid 
memeriksa pekerjaan mereka sendiri, guru mengamati dan mengajukan pertanyaan-pertanyaan.

d, Pengajaran yang bersifat individual, sehingga tidak ada tes ataupun buku kerja

e. Guru mempersepsi dengan cara mengamati setiap proses yang dilalui murid dan membuat catatan dan penilaian secara individual, hanya sedikit sekali diadakan tes formal.

f. Adanya kesempatan untuk pertumbuhan professional bagi guru, dalam arti guru boleh menggunakan bantuan orang lain termasuk rekan sekerjanya.

g. Suasana kelas yang hangat dan ramah sehingga mendukung proses belajar yang membuat murid nyaman dalam melakukan sesuatu.

Perlu untuk diketahui, bahwa penelitian tentang efektivitas model ini menunjukkan adanya perbedaan dengan proses pendidikan tradisional dalam hal kreativitas, dorongan berprestasi, kebebasan dan hasil-hasil yang bersifat afektif secara lebih baik. Akan tetapi dari segi pencapaian prestasi belajar akademik, pengajaran tradisional lebih berhasil dibandingkan poses pendidikan terbuka ini.

\section{Cooperative Learning atau Belajar Kooperatif}

Belajar kooperatif merupakan fondasi yang baik untuk meningkatkan dorongan berprestasi murid. Dalam prakteknya, belajar kooperatif memiliki tiga karakteristik :

a. Murid bekerja dalam tim-tim belajar yang kecil $(4-6$ orang anggota), dan komposisi ini tetap selama beberapa minggu.

b. Murid didorong untuk saling membantu dalam mempelajari bahan yang bersifat akademik dan melakukannya secara berkelompok.

c. Murid diberi imbalan atau hadiah atas dasar prestasi kelompok.

Adapun teknik-teknik dalam belajar koperatif ini ada 4 (empat) macam, yakni :

a. Team-Games-Tournament

Dalam teknik ini murid-murid yang kemampuan dan jenis kelaminnya berbeda disatukan dalam tim yang terdiri dari empat sampai lima orang anggota. Setelah guru menyajikan bahan pelajaran, lalu tim mengerjakan lembaran-lembaran kerja, saling 
mengajukan pertanyaan, dan belajar bersama untuk persiapan menghadapi perlombaan atau turnamen yang diadakan sekali seminggu. Dalam turnamen penentuan anggota tim berdasarkan kemampuan pada minggu sebelumnya. Hasilnya, murid-murid yang berprestasi paling rendah pada setiap kelompok memiliki peluang yang sama untuk memperoleh poin bagi timnya sebagai murid yang berprestasi paling tinggi.

Adapun jalannya turnamen adalah para murid secara bergantian mengambil kartu dan menjawab pertanyaan-pertanyaan yang tertera pada kartu itu, yakni pertanyaan yang sesuai dengan materi yang telah dipelajari selama seminggu itu. Pada akhir turnamen, guru menyiapkan lembar berikut tentang tim-tim yang berhasil dan skor-skor tertinggi yang dicapai.

Meskipun keanggotaan tim tetap sama, tetapi tiga orang yang mewakili tim untuk bertanding dapat berubah-ubah atas dasar penampilan dan prestasi masing-masing anggota. Misalnya saat ini prestasi murid rendah dan ia bertanding dengan murid lain yang kemampuannya serupa, maka minggu berikutnya ia bisa saja bertanding melawan murid-murid yang berprestasi tinggi manakala ia menjadi lebih baik.

\section{b. Student Teams-Achievement Divisions}

Teknik ini menggunakan tim yang terdiri dari empat sampai lima orang anggota, akan tetapi kegiatan turnamen diganti dengan saling bertanya selama lima belas menit, dimana pertanyaanpertanyaan yang diajukan terlebih dulu disusun oleh tim. Skorskor pertanyaan diubah menjadi skor-skor tim, skor-skor yang tertinggi memperoleh poin lebih dari pada skor-skor yang lebih rendah, disamping itu juga ada skor perbaikan.

c. Jigsaw

Murid dimasukkan ke dalam tim-tim kecil yang bersifat heterogen, kemudian tim diberi bahan pelajaran. Murid mempelajari bagian masing-masing bersama-sama dengan anggota tim lain yang mendapat bahan serupa. Setelah itu mereka kembali ke kelompoknya masing-masing untuk mengajarkan bagian yang telah dipelajarinya bersama dengan anggota tim lain tersebut, kepada teman-teman dalam timnya sendiri. Akhirnya semua anggota tim dites mengenai seluruh bahan pelajaran. Adapun skor yang diperoleh murid dapat ditentukan melalui dua cara, yakni skor untuk masing-masing murid dan skor yang digunakan untuk membuat skor tim. 


\section{d. Group Investigation}

Disini para murid bekerja di dalam kelompok-kelompok kecil untuk menanggapi berbagai macam proyek kelas. Setiap kelompok membagi tugas tersebut menjadi sub-sub topik yang dibebankan kepada setiap anggota kelompok untuk menelitinya dalam rangka mencapai tujuan kelompok. Setelah itu setiap kelompok mengajukan hasil penelitiannya kepada kelas.

Berdasarkan penelitian, teknik-teknik belajar kooperatif pada umumnya berefek positif terhadap prestasi akademik. Selain itu teknik ini juga meningkatkan perilaku kooperatif dan altruistic murid. Dengan demikian dapat disimpulkan bahwa teknik ini merupakan teknik mengajar yang efektif untuk mencapai tujuan instruksional kelas.

\section{Independent Learning (Pembelajaran Mandiri)}

Pembelajaran Mandiri adalah proses pembelajaran yang menuntut murid menjadi subjek yang harus merancang, mengatur dan mengontrol kegiatan mereka sendiri secara bertanggung jawab. Proses ini tidak bergantung pada subjek maupun metode instruksional, melainkan kepada siapa yang belajar (murid), mencakup siapa yang memutuskan tentang apa yang akan dipelajari, siapa yang harus mempelajari sesuatu hal, metode dan sumber apa saja yang akan digunakan, dan bagaimana cara mengukur keberhasilan upaya belajar yang telah dilaksanakan (Lowry, dalam Harsono, 2007).

Dalam pelaksanaannya, proses ini cocok untuk pembelajaran di tingkat atau level perguruan tinggi, karena menuntut kemandirian yang tinggi dari peserta didik. Di sini pendidik beralih fungsi menjadi fasilitator proses belajar, bukan sebagai penentu proses belajar. Meski demikian, pendidik harus siap untuk menjadi tempat bertanya dan bahkan diharapkan pendidik betul-betul ahli di bidang yang dipelajari peserta.

Agar tidak terjadi kesenjangan hubungan antara peserta dan pendidik, perlu dilakukan negosiasi dalam perancangan pembelajaran secara keseluruhan (Harsono, 2007). Perancangan pembelajaran ini merupakan alat yang fleksibel tetapi efektif untuk membantu peserta didik dalam penentuan tujuan belajar secara individual. Tanggung jawab peserta didik dan pengajar harus dibuat secara eksplisit dalam perancangan pembelajaran. Partisipasi para peserta didik dalam penentuan tujuan belajar akan membuat mereka lebih berkomitmen terhadap proses pembelajaran. 


\section{Student Centered Learning (Belajar yang Terpusat pada Siswa)}

Student Centered Learning atau disingkat SCL merupakan strategi pembelajaran yang menempatkan peserta didik secara aktif dan mandiri, serta bertanggung jawab atas pembelajaran yang dilakukan. Dengan SCL peserta diharapkan mampu mengembangkan ketrampilan berpikir secara kritis, mengembangkan system dukungan social untuk pembelajaran mereka, mampu memilih gaya belajar yang paling efektif dan diharapkan menjadi life-long learner dan memiliki jiwa entrepreneur.

Sama seperti model sebelumnya, SCL banyak diterapkan dalam system pendidikan di tingkat Perguruan Tinggi (Harsono, 2007). Dengan SCL mahasiswa memiliki keleluasaan untuk mengembangkan segenap potensinya (cipta, karsa dan rasa), mengeksplorasi bidang yang diminatinya, membangun pengetahuan dan mencapai kompetensinya secara aktif, mandiri dan bertanggung jawab melalui proses pembelajaran yang bersifat kolaboratif, kooperatif dan kontekstual.

Adapun metode-metode SCL antara lain :

\section{a. Cooperative Learning (Pembelajaran Kooperatif)}

Prinsip metode ini adalah mahasiswa belajar dari dan dengan teman-temannya untuk mencapai suatu tujuan belajar dengan secara penuh bertanggung jawab atas hasil pembelajaran yang dicapai (Afiatin, 2007). Disini dosen membagi otoritas dengan para mahasiswa. Secara detail prosedur yang dilakukan dalam metode ini adalah :

- Dosen menjelaskan topik yang akan dipelajari

- Kelas dibagi menjadi kelompok-kelompok kecil, setiap kelompok terdiri dari $5-7$ orang

- Dosen membagi sub-sub topik kepada masing-masing kelompok, disertai dengan pertanyaan atau tugas-tugas yang berkaitan dengan masing-masing sub topik

- Dosen meminta masing-masing kelompok mendiskusikan, menjawab pertanyaan atau mengerjakan tugas-tugas pada masing-masing sub topik

- Dosen meminta masing-masing kelompok mempresentasikan hasil diskusi atau pekerjaannya dalam kelompok

- Dosen memfasilitasi pembahasan topik secara menyeluruh dalam 
kelas

\section{b. Collaborative Learning (Pembelajaran Kolaboratif)}

Prinsip dari Pembelajaran Kolaboratif adalah bahwa pembelajaran merupakan proses yang aktif. Mahasiswa mengasimilasi informasi dan menghubungkannya dengan pengetahuan baru melalui kerangka acuan pengetahuan sebelumnya. Pembelajaran memerlukan suatu tantangan yang akan membuka wawasan para mahasiswa untuk secara aktif berinteraksi dengan temannya. Di sini mahasiswa akan mendapatkan keuntungan lebih jika mereka saling berbagi pandangan yang berbeda dengan temannya (Afiatin, 2007).

Pembelajaran terjadi dalam lingkungan sosial yang memungkinkan terjadinya komunikasi dan saling bertukar informasi, yang akan memudahkan mahasiswa menciptakan kerangka pemikiran dan pemaknaan terhadap hal yang dipelajari. Mahasiswa ditantang baik secara sosial maupun emosional ketika menghadapi perbedaan perspektif dan memerlukan suatu kemampuan untuk dapat mempertahankan ide-idenya. Dengan demikian melalui proses ini mahasiswa belajar menciptakan keunikan kerangka konseptual masing-masing dan secara aktif terlibat dalam proses membentuk pengetahuan.

Adapun prosedur pembelajaran kolaboratif adalah sebagai berikut :

- Dosen menjelaskan topik yang akan dipelajari

- Dosen membagi kelas menjadi kelompok-kelompok kecil yang terdiri dari 5 orang

- Dosen membagi lembar kasus yang terkait dengan topik yang dipelajari

- Mahasiswa diminta membaca kasus dan mengerjakan tugas yang terkait dengan persepsi dan solusi terhadap kasus

- Mahasiswa diminta mendiskusikan hasil pekerjaannya dalam kelompok kecil masing-masing dan mendiskusikan kesepakatan kelompok

- Masing-masing kelompok mempresentasikan hasil diskusi kelompoknya dalam kelas dan meminta kelompok lain untuk memberikan tanggapan

\section{c. Competitive Learning (Pembelajaran Kompetitif)}

Prinsip pembelajaran ini adalah memfasilitasi mahasiswa saling berkompetisi dengan temannya untuk mencapai hasil terbaik. 
Kompetisi dapat dilakukan secara individual maupun kelompok. Kompetisi individual berarti mahasiswa berkompetisi dengan dirinya sendiri dibandingkan dengan pencapaian prestasi sebelumnya. Kompetisi kelompok dilakukan dengan membangun kerjasama kelompok untuk dapat mencapai prestasi tertinggi (Afiatin, 2007).

Prosedur proses pembelajaran kompetitif adalah sebagai berikut

:

- Dosen menjelaskan tujuan pembelajaran

- Dosen membagi kelas menjadi kelompok-kelompok kecil dengan jumlah anggota $5-7$ orang

- Dosen menjelaskan prosedur tugas yang akan dikompetisikan dan standar penilaiannya

- Dosen memfasilitasi kelompok untuk dapat mengerjakan tugas dengan sebaik-baiknya

- Masing-masing kelompok menunjukkan kinerjanya

- Dosen memberikan penilaian terhadap kinerja kelompok berdasar standar kinerja yang telah disepakati

\section{d. Case Based Learning (Pembelajaran Berdasar Kasus)}

Prinsip dasar dari metode ini adalah memfasilitasi mahasiswa untuk menguasai konsep dan menerapkannya dalam praktek nyata. Dalam hal ini analisis kasus yang dikuasai tidak hanya berdasarkan common sense melainkan dengan bekal materi yang telah dipelajari. Pada akhirnya metode ini memfasilitasi mahasiswa untuk berkomunikasi dan berargumentasi terhadap analisis suatu kasus (Afiatin, 2007).

Prosedur yang dilakukan dalam metode ini adalah :

- Dosen menjelaskan tujuan pembelajaran dan metode yang akan digunakan

- Dosen meminta mahasiswa mempelajari konsep dasar yang berkaitan dengan tujuan pembelajaran, dengan cara membaca buku teks yang membahas materi tersebut.

- Dosen membagikan lembar kasus yang telah dipersiapkan, dimana kasus ini haruslah relevan dengan tujuan dan materi pembelajaran

- Dosen membagikan lembar pertanyaan yang harus dijawab oleh mahasiswa berkaitan dengan pembahasan kasus tersebut. Pertanyaan harus disusun sedemikian rupa sehingga menjadi panduan mahasiswa untuk dapat menganalisis kasus berdasarkan 
konsep dasar yang telah dipelajari

- Dosen meminta masing-masing mahasiswa mempresentasikan hasil analisis kasusnya. Mahasiswa dan dosen dapat memberikan tanggapan terhadap presentasi yang disajikan.

Pada intinya, pembelajaran dengan SCL sangat bertentangan dengan proses pembelajaran konvensional yang cenderung Teacher Centered Instruction, yakni proses pembelajaran yang mengandalkan guru atau dosen sebagai sentralnya. Di sini nampak aplikasi dari aliran humanistik, yang sangat 'memanusiakan' peserta didik.

\section{Penutup}

Psikologi humanistik sangat relevan dengan dunia pendidikan, karena aliran ini selalu mendorong peningkatan kualitas diri manusia melalui penghargaannya terhadap potensi-potensi positif yang ada pada setiap insan. Seiring dengan perubahan dan tuntutan zaman, proses pendidikan pun senantiasa berubah. Dengan adanya perubahan dalam strategi pendidikan dari waktu ke waktu, humanistik memberikan arahan yang signifikan dalam pencapaian tujuan ini.

\section{DAFTAR PUSTAKA}

Afiatin, T. 2007. Strategi Pembelajaran dengan Paradigma Student Centered Learning (makalah dalam Lokakarya Peningkatan Pembelajaran melalui SCL, FPISB UII, Yogyakarta, 4 April 2007).

Harsono, 2007. Student Centered Learning (makalah dalam Lokakarya Peningkatan Pembelajaran melalui SCL, FPISB UII, Yogyakarta, 4 April 2007).

Roberts, T. B., 1975. Four Psychologies Applied to Education : Freudian, Behavioral, Humanistic, Transpersonal. New York: Schenkman Pub. Co.

Rumini, S. dkk. 1993. Psikologi Pendidikan. Yogyakarta: Fakultas Ilmu Pendidikan Universitas Negeri Yogyakarta

Walgito, B. 2000. Peran Psikologi di Indonesia (Kumpulan Pidato Pengukuhan Guru Besar Fakultas Psikologi UGM). Yogyakarta: Yayasan Pembina Fakultas Psikologi UGM. 